\title{
Understanding Resistant Vietnamese Learners of English from an Activity Theory Perspective
}

\author{
Thi Khanh Doan Nguyen \\ Soc Trang Community College, Soc Trang, Vietnam
}

\author{
Steven Pickford \\ University of Wollongong, New South Wales, Australia \\ Barbra McKenzie \\ University of Wollongong, New South Wales, Australia
}

\begin{abstract}
This paper aims to explore the reasons for learner resistance in the language classroom. English language learners may resist joining in the process of responding to language tasks. However, under activity theory, a number of sociocultural factors in the language classroom may result in such a task performance. Participants in this study were college students and teachers of English. The data collection methods were class observations, stimulated recall with the students, and semi-structured interviews with the teachers. The results indicate that resistant learners were viewed as problematic and passive in the eyes of teachers. However, seemingly passive students saw themselves as internally active. Additionally, students pointed out personal and sociocultural factors in the class which resulted in their resistance during the class. This paper suggests that teachers may consider the role of learner agency when evaluating learners' performance.
\end{abstract}

Recently, the cognitive approach to language learning has been critiqued because it does not consider the contextual and sociocultural elements which influence language learning (Yashima 2012). For instance, Nunan (2004) argued that language learning is not only a personal but also a highly social process. Thus, researchers have called for the adoption of sociocultural perspectives on the language learning process (Gebhard, 1999). Through the lens of sociocultural perspectives, learners are perceived as people in the learning process, so learner agency must be accounted for in that process (Lantolf \& Pavlenko, 2001). From this perspective, Lantolf and Pavlenko (2001) contended that learners may choose to fully or peripherally participate in the community of learning. Studies in this line are distinct from those advocating cognitive views that focus only on learners' internal characteristics (e.g., level of English proficiency) to explain learning performance.

Sociocultural studies adopt the perspective that individual development is a socially mediated process, and that language learning is an activity determined by both personal factors of the individual and sociocultural factors of the learning context. Seen from this view, activity theory, which is a critical component of sociocultural theory, is a powerful standpoint from

Language Education in Asia, 2016, オ1), 32-43. http://dx.doi.org/10.5746/LEiA/16/V7/I1/A04/Nguyen_Pickford_McKenzie 
which learning activity might be viewed (Lantolf \& Thorne, 2006). Since learning is equated to an activity in a specific context, factors in that context will affect it (Yashima, 2012).

In application of this view to learners' performance in language classrooms, those unlikely to follow the normative classroom discourse must be reconsidered. Learner resistance is often seen as negative in the classroom. For example, Norton and Toohey (2001) showed that teachers designate students choosing to exclude themselves from classroom activities as poor or unmotivated learners. Under activity theory, nevertheless, understanding their performance in a context of learning requires attention to social practices in that specific context (Sirisatit, 2010). Consequently, a focus on activity theory may throw light on how learners situate themselves in the context (Norton \& Toohey, 2011).

Arising from an interest in understanding learner resistance, which is noted as a problem for language teachers (Tran \& Richard, 2007), this paper aims to shed light on such language learning performances during English classes. The study will be viewed within the context of Vietnamese language education to gain insights into the reasons behind learner resistance and how teachers perceive it in their class. The study may help English language teachers in Vietnam and in similar settings to develop an understanding of learner agency so they may foster learner participation in the language classroom.

\section{Literature Review}

\section{Learner Agency}

Gao (2010) defined agency as a person's will or ability to act, while the term earlier was described as "the socio-culturally mediated capacity to act" (Ahearn, 2001, p. 112). In the second language learning context, agency may refer to the perspective that learners are not only submissive or complicit, but can also resist or make informed choices about learning (Duff, 2012). The notion of agency is, therefore, considered as behavior that facilitates learning, such as participation and actively seeking out assistance within a context which is socially mediated (Hawkins, 2005). However, agency also relates to learners' actions that do not lead to participation or positive learning outcomes (Harklau, 2000; Morita, 2004). Language learners may actively participate in or resist learning tasks depending on the sociocultural and interactional context. In the event that class conditions are favorable, they would be active; if conditions are not, students may remain passive in classroom activities. Therefore, learner agency is mediated and renegotiated with the social and cultural factors present in the classroom (Lantolf \& Thorne, 2006).

However, Fogle (2012) demonstrated the limitation of the treatment of agency in second language studies. The author indicated that there has been over-attention on one type of agency (i.e., complicit or participatory agency), whereas resistance to the target language, which is also a form of learner agency, has not been widely explored. Hence, the present paper examines this type of agency. With respect to the present paper, the researchers argue that learners may exercise their agency through being active or resistant during task engagement determined by social conditions in that classroom.

\section{Learner Resistance}

As aforementioned, agentive responses towards language learning may be in the form of resistance. Duff (2012) and Ahearn (2001) identified resistance as one form of agency occurring in and through discourse. In reference to second language learning, resistance (e.g., being silent) is often perceived as a type of avoidance or deliberate failure to replicate target language norms (Morita, 2004). Based on the notion that as a sense of agency learners would 
shape their own learning in the context where they are situated, the researchers argue that learners may conduct a task in ways varied from that required by the teacher. Therefore, the term learner resistance in the present paper is confined to learners who are silent or disregard classroom norms.

These forms of agency are hard to recognize because teachers may interpret them in negative ways (Skinnari, 2014). Resistance to second language learning is often viewed as the cause of problematic outcomes such as troubles at school or not learning (Harklau, 2000). This is a view shared by Fogle (2012), who argued that such misinterpretation may result in the marginalization of learners through their failure to participate. Nevertheless, as stated previously, learners' performance in a class is influenced by sociocultural factors in that class. Activity theory provides a useful framework to illuminate underlying reasons for learners' task performance (Lantolf \& Thorne, 2006). Accordingly, activity theory is adopted as a framework in the present paper to obtain improved insights into language learners who appeared to be silent or resistant during classroom activities.

\section{Activity Theory}

Activity theory was developed by Engeström (1987), based upon the work of Vygotsky (1978) and Leontiev (1979). The theory represents individual actions within a broader collaborative setting through six elements: tools, subject, object, rules, community, and division of labor.

Tools. Tools are the devices that humans use to act on the physical world (Vygotsky, (1978). Tools in this study refer to the instruments that learners employ to complete the language task. Hence, the tools in use may include textbooks, video-audio materials, or diagrams, to name a few. Sirisatit (2010) argued that the mediational tools that learners use may influence the way learners perform a task. From this perspective, the tools being used may result in silence or resistance among learners.

Subject. Subject in this paper refers to learners, and subject is the central and driving characteristic defining the activity. Yashima (2012) reasoned that learners with their own language learning goals, motives, linguistic history, and beliefs will determine their activities in responding to a specific task. In reference to this study, these factors may contribute to learner resistance in class.

Object. Object is defined as the purpose or the goal held by learners when engaging in a language task. For example, an individual's object toward a task may be to pass an exam, to master a grammatical rule or to improve his or her speaking skill. Lantolf and Thorne (2007) showed that in alignment with certain goals, learners may then conduct different goal-directed actions during the completion of the task. Therefore, learners may be resistant to the given task due to their object being different from the teacher's object.

Community. Community involves various individuals or groups of people sharing the same general object towards an activity (Sirisatit, 2010). In this paper, community includes the class teacher and peers who contribute to similar objects of a given task. Norton (2001) noted that the extent to which learners participate in the practices of a community depends on the favorable conditions created by that community.

Rules. Rules are perceived as any formal or informal regulations that determine how and why individuals may act (Hashim \& Jones, 2007). In this paper, rules refer to task rules, scoring rubrics of the English class, or the normative classroom discourse. These may make learners resistant or silent in a task. 
Division of labor. In the language classroom, division of labor is construed as the formation of pairs or groups of students when fulfilling an assigned task (Sirisatit, 2010). Noticeably, Lantolf and Genung (2002) and Sirisatit (2010) emphasized that forms of division of labor contribute to the success or failure of task performance. In relation to this study, a learner may or may not prefer groupwork or pairwork, hence causing silence or resistance during the task engagement.

Generally, through activity theory, a sense of agency identifies the level of learner participation in a language task (Yashima, 2012). Learners appear to be silent or resistant to language tasks due to sociocultural factors in the classroom as well as their own personal factors. However, as argued earlier, learner agency may be misinterpreted by teachers. Accordingly, the present research aims to find answers to the following questions:

1. How do class teachers perceive learners who are silent or resistant in the classroom?

2. Why do students appear to be silent or resistant in response to classroom tasks?

\section{Methodology}

Through the lens of activity theory, a language class is considered a sociocultural context that is changing constantly, and language learners are viewed as agents mediated by the sociocultural factors within that learning context. Thus, experimental research designs are inappropriate for the present study because such designs perceive that learners could be manipulated by the intentions of the researcher and by task instruction. Therefore, the study adopted a qualitative research design.

\section{Participants}

Because qualitative studies seek to understand a phenomenon in depth and detail rather than to generalize their results, this study applied convenient and purposive sampling strategies. The study was conducted and the data were collected in a college in the Mekong Delta of Vietnam, where the one of the researchers has worked as an English teacher. The participants of the study were second-year non-English major students aged from 19 to 21 and their English teachers. They were asked to volunteer for the study and two classes agreed to participate. One class involved 20 students who were majoring in accounting, while the other had 21 students majoring in business administration. The former was taught English by a female teacher with 10 years' experience of teaching English. The latter was taught English by a male teacher who had been teaching English for 5 years. According to the written test (focusing on listening, reading, and writing) conducted at the beginning of the course, student English proficiency ranged from elementary (A1) to upper-intermediate (B2) based on the Common European Framework of References for Languages (CEFR). They studied English as a compulsory subject for graduation. The English course lasted nine weeks, equating to three credits, with five 45-minute class meetings every week. According to the purpose of the study, the researchers focused their attention on students showing silence or resistance during her presence at the research site. The participants are identified by pseudonyms.

\section{Class Observation}

Observations were conducted in the two classes over four class meetings with the teacher's permission. These observations aimed to note learners who were apparently silent and resistant during tasks. While observing the classes, the researcher took the role of a "nonparticipant" (Creswell, 2013, p. 167). She observed, took field notes, and recorded data without involvement in participants' activities. Additionally, video recordings were used to capture learners' interactions which might be missed during the observations. 


\section{Stimulated Recall}

Lyle (2003) suggested that stimulated recall is a useful research tool as it helps to uncover thinking processes which may not be evident through simple observation. In this study, stimulated recall was used to assist the researchers to investigate what students thought while engaging in the tasks. Students who demonstrated silence and resistance while participating in their task performance were asked to participate in the stimulated recall. Immediately after each observed class, they were shown selected video excerpts and asked about their thoughts and reasons while dealing with a task at a critical point.

\section{Semi-Structured Interviews}

Interviews with the two class teachers, conducted at the end of the course, aimed to shed light on their perceptions of learner resistance. They were asked to express their perspectives concerning learners being silent or resistant (e.g., reasons for and solutions to the issue).

Regarding the learners' English proficiency and the research aims, which were focused on the information given by participants, interviews and stimulated recall sessions were all conducted in Vietnamese, the native language shared by the participants and the researcher. The stimulated recall and the interviews were audio-recorded. The data were transcribed and analyzed through the use of content analysis.

\section{Findings and Discussion \\ Teacher Perspectives on Learner Resistance}

Interviews with teachers demonstrated that both teachers regarded remaining silent and defying normative classroom practices as negative behavior and problematic to English learning. Teacher 1 revealed her unhappiness with resistant learners who she thought did not obey the class teacher.

I am so unhappy with some students who always do the tasks in their own ways in spite of whatever my requirements are ... I ask them to do A, and they will do B. (Teacher 1)

She provided an example of students translating whole reading passages while she requested them to skim or scan the passage. She then stated:

At first I think they have their heads in the clouds, but then I find that they always disregard my instructions. They just do the way they like ... it's disrespectful to their teachers. (Teacher 1)

This is similarly shared with the second teacher who found resistant students annoying.

I am annoyed when I try to remind them of doing exercises in alignment with the requirements. They are in the process of learning so they need to follow the teacher's instruction as well as instructions in the textbook. They should first complete the exercises as the teacher expects. (Teacher 2)

As an example, he identified one student in his class who never did speaking tasks or writing tasks in the order of the given questions, and another student who appeared not to cooperate with other students in group work or pair work.

When asked what they did for these students, both teachers said that they ignored them. 
It just takes my time to pay attention to these students who never account for their teacher's instructions. (Teacher 1)

They are just some in one class of many students so I don't care about them. (Teacher 2)

For silent students, both teachers perceived them as lower proficiency and inactive learners.

They rarely speak up in the class because they are not quite confident in their English. (Teacher 2)

For me, they are such passive learners of language who just sit and never speak. It's not good to learn a language in that way. (Teacher 1)

They also claimed that these students would get lower marks than active students. Teacher 1 reasoned that:

It's fair that if they want to get high marks for their participation they should say something, do something which shows that they are learning the language.

(Teacher 1)

Class participation was one of the criteria to evaluate students' subject completion in both classes. The in-class written tests were worth $70 \%$, and class participation amounted to $30 \%$ of the total grade. Therefore, students who actively participated in the class would get higher grades than others who were passive.

These results are in line with research conducted by Morita (2004) and Harklau (2000), who indicated that student silence or resistance are often equated with deficiency in the eyes of their teachers. As criticized by Norton and Toohey (2001), teachers just evaluate good learners on the basis of "their control of a wider variety of linguistic forms or meaning than their peers" ( $p$. 310).

\section{Reasons for Learner Resistance During Task Accomplishment}

The data collected from stimulated recall by students who were passive and resistant during the task completion revealed some reasons for their behavior. Under activity theory, it could be summarized that subject, object, community, and division of labor determined the students' task performance in this study.

Subject. In terms of the subjects, Students B and C's actions might illustrate that learning history and prior experience strongly influenced their task performance. Student $C$, who tended to be silent, revealed that her language learning history shaped the way she conducted the task. She had studied English with a teacher who was nice and cared about her grammar. Thus, she had really liked English at that time and equated English learning to learning English grammar and being with caring teachers. However, her subsequent teachers were different, so she lost interest in English learning. She wished some teachers of English could help her with English grammar to motivate her English learning.

They just want to finish their job by keeping asking us to speak but never care about what I really need [grammar] since once I master English grammar I can speak and write English well. (Student C) 
Likewise, Student B, who had family problems, avoided talking about topics related to family. Hence, he talked about questions related to this at the end though the teacher might expect him to answer these questions at first.

When introducing myself I do not like to talk about my family because my parents died when I was very young. Since then, I've been living with my grandparents. I feel lost and upset when someone asks me about my family. Thus, I will leave this in the end. (Student B)

This finding illustrates the view that various linguistic histories or prior experiences affect learners' task performance. This is aligned with the study conducted by Gillette (1994). The study points out that learners' prior experience has an impact on their language learning perceptions, which in turn may influence their behavior towards language learning in class.

Object. Furthermore, the study shows that students might find their desired object in conflict with the teacher's object, so they resist what is assigned by the teacher. For example, Student A wanted to translate the reading text, not just scan or skim it, because he preferred to understand the whole text.

The teacher sometimes asks us to read and then answer the questions following the reading passage, but I think the exercise is as easy as pie when we can just guess the right answers. We are encouraged to ignore unknown words, but I want to understand what the passage is about because I need to learn new words as well as structures in the passage. (Student A)

Similarly, Student $\mathrm{C}$ admitted that she favored acquiring grammatical points while her teachers of English focused on speaking instead, thus causing her refusal to engage in the task activities.

It's disappointing that the teacher totally ignores the thing I need - grammar. (Student C)

Community. Another finding indicates that the community where students conducted the task might make them quiet or active. Student E illustrated this point; when the learning community consisted of more capable students, she lost her confidence and became silent.

To be honest, I don't feel like working with very good classmates since they may pick up my mistakes easily . . . I find they never take account the contribution from their friends worse than them, like me ... I feel I'm inferior to them; thus, I just keep silent. (Student E)

However, when the community consisted of others who were of the same or lower English proficiency level, she felt more confident and became active.

I feel much more comfortable to work with these students. We take the contribution of each of us into a lot of consideration ... They sometimes appreciate my ideas since they know that I'm a bit better than them . . . This makes me feel confident. (Student E)

This result relates to aspects of Duff's (2002) research which revealed how non-native English speaking international learners chose to be silent to save face when grouped with more 
proficient local learners. When located in a community of more proficient peers, some learners may refuse to engage in the task.

Division of labor. The study demonstrates that fulfilling tasks in groups or pairs might discourage some learners from joining the discussion. Student $F$ reported that he refused to cooperate with other classmates during tasks though he belonged to the group of more advanced students. He then stated that he did not favor collaborative tasks.

Groupwork is just unfair since not all members do the task but just one or two who are responsible, and the result is then shared. . . Moreover, I have to respect ideas from others, which are not always good. I go with working alone with my dictionary. (Student F)

This result is similar to that found by Parks (2000), which showed that one of the participants preferred working alone rather than cooperatively with others since she perceived groupwork as being a form of groupthink where students were not required to think for themselves. This suggests that dislike for a certain type of division of labor (e.g., groupwork or pairwork) may detract from participation in a task.

Interestingly, remaining silent is not equated to not learning. Although Student $\mathrm{C}$ remained silent in the class, she stated that she studied in her own ways. For example, after a task requiring students to make a conversation based on a reading passage, she said:

While my friends are making the conversation, I like to underline grammar points new to me. I ask my classmates to explain these points for me. I then self-study these at home. (Student C)

This might be useful for her when dealing with in-class tests, thus leading to high results in the tests requiring no oral performance.

I get low marks for the class participation but I'm proud of 45-minute tests for which I always achieve quite good marks. (Student C)

Similarly, both Students E and D affirmed that although they rarely actively participated in class activities, they actually learned through carefully taking notes and listening to others. For example, Student D, who seldom raised his hand to speak in class, stated:

I try to listen and take notes of the feedback from the teacher and classmates. I compare how my friends' answers are different from mine. (Student D)

In spite of being silent when grouped with more advanced students, Student E said that she learned English from her groupmates.

I'm learning the way they express an idea in English ... I've picked up a new interesting expression, "cost an arm and a leg." (Student E)

Students were passive during discussions, but they might have been learning internally. Listening attentively and concentrating on a task are ways of active participation among silent learners. This finding is shared with Skinnari (2014), where remaining silent in language classrooms may have a positive effect on language learning. In Skinnari's (2014) study, Finnish 
elementary learners who were quiet during their English class confirmed that their silence meant attentive listening and concentrating on the task.

\section{Conclusion}

Under the framework of activity theory, the findings demonstrate that learners act as agents of their own learning activity, thereby causing resistance among some of them when working on a task. Remaining silent or resistant proves that learners actively construct their learning position in a specific learning context. In their negotiation with the social context, they may choose to exclude themselves from engaging in a task. As shown in the study, they might refuse to work with some partners (e.g., more advanced learners). Their learning perceptions, histories or prior experience determine their task performance. Learners might also conduct the task in their own way to suit their learning objects. However, teachers might misinterpret such learner task performance as passive or negative behavior which affects language learning.

The study suggests that teachers may find it useful to consider both social and personal factors when assessing learner task performance, especially in relation to students who are passive or resistant to classroom norms. The silent students stated that they learned and participated in tasks internally. By critically reflecting on these students, teachers may have opportunities to learn more about the nature of their instruction and students' needs. Therefore, teachers may reposition these students from disruptive or deficient to valuable classroom participants.

Evaluating language learning requires the consideration of sociocultural practices in the context where the language is learned and the examination of the ways that learners exercise their agency in that context (Norton \& Toohey, 2001).

Teachers may learn about their students through a brief survey at the beginning of the course or through explicit discussions about their language learning beliefs and goals, therefore enabling understanding of their language learning history and learning object. Accordingly, teachers will be better able to select the topics, methods, and behavior more suited to their students. As a result, learner participation in language tasks may improve.

This study paves the way for other research in learners' task engagement in the Vietnamese context or in other Asian contexts from the perspective of activity theory. In particular, to understand learners who are resistant, it utilizes the concept of agency, which is undertheorized in SLA research.

However, the study has limitations. The data were collected in four class meetings because time for data collection depended on class teachers' permission. Further studies should involve someone who is not a member of the college to help the researcher with observing the class at some point during the data collection. This may avoid worry or anxiety among the participants. Additionally, more students could be involved in the stimulated recall process. Interviews with class teachers should be conducted more often (e.g., at the end of every lesson). Further studies may also focus upon other components of the English learning activity system, such as Rules and Tools and their relation to learner resistance since these were not a focus in this study. 


\section{Author Note}

Thi Khanh Doan Nguyen, Department of Foreign Language Studies, Soc Trang Community College, Soc Trang, Vietnam; Steven Pickford, School of Education, University of Wollongong, New South Wales, Australia; Barbra McKenzie, School of Education, University of Wollongong, New South Wales, Australia.

Thi Khanh Doan Nguyen is a teacher of English at Soc Trang Community College. She earned her B.Ed from Nong Lam University and M.Ed in TESOL from Can Tho University. She is currently pursuing her Ed.D at University of Wollongong, Australia. Her research interests include language teaching methods and sociocultural theory.

Steven Pickford is a senior TESOL lecturer at University of Wollongong. His work experience includes teaching, curriculum writing, research, and publication in second language education in Papua New Guinea, Indonesia, Thailand, and Australia. His research interests include second language classroom discourse, cultural pedagogies in TESOL, and sociolinguistics of language education.

Barbra McKenzie is a senior lecturer and Teacher Education Co-ordinator in Language and Literacy in the School of Education, Faculty of Social Science, at the University of Wollongong, Australia. Her research interests include Sensemaking Theory in organisations and exploring the relationships between teacher professional development and classroom practice.

Correspondence concerning this article should be addressed to Thi Khanh Doan Nguyen, Soc Trang Community College, 400 Le Hong Phong, Ward 3, Soc Trang City, Vietnam. E-mail: nguyenthikhanhdoan@gmail.com 


\section{References}

Ahearn, L. M. (2001). Language and agency. Annual Review of Anthropology, 30, 109-137. http://dx.doi.org/10.1146/annurev.anthro.30.1.109

Creswell, J. W. (2013). Qualitative inquiry and research design: Choosing among five approaches. Thousand Oaks, CA: SAGE.

Duff, P. A. (2002). The discursive co-construction of knowledge, identity, and difference: An ethnography of communication in the high school mainstream. Applied Linguistics, 23(3), 289-322. http://dx.doi.org/10.1093/applin/23.3.289

Duff, P. A. (2012). Identity, agency and second language acquisition. In S. M. Gass \& A. Mackey (Eds.), The Routledge handbook of second language acquisition (pp. 410-426). London, England: Routledge.

Engeström, Y. (1987). Learning by expanding: An activity theoretical approach to developmental research. Helsinki, Finland: Orienta-Konsultit.

Fogle, L. W. (2012). Second language socialization and learner agency: Adoptive family talk. Bristol, England: Multilingual Matters.

Gao, X. (2010). Strategic language learning: The roles of agency and context. Clevedon, England: Multilingual Matters

Gebhard, M. (1999). Debates in SLA studies: Redefining classroom SLA as an institutional phenomenon. TESOL Quarterly, 33, 544-544. http://dx.doi.org/10.2307/3587679

Gillette, B. (1994). The role of learner goals in L2 success: Sociocultural theory and children with special needs. In J. P. Lantolf \& G. Appel (Eds.), Vygotskian approaches to second language research. Norwood, NJ: Ablex.

Harklau, L. (2000). From the "good kids" to the "worst": Representation of English language learners across educational settings. TESOL Quarterly, 34(1), 35-67. http://dx.doi.org/10.2307/3588096

Hashim, N. H., \& Jones, M. L. (2007). Activity theory: A framework for qualitative analysis. Retrieved from http://ro.uow.edu.au/cgi/viewcontent.cgi?article=1434\&context=commpapers

Hawkins, M. (2005). Becoming a student: Identity work and academic literacies in early schooling. TESOL Quarterly, 39(1), 59-82. http://dx.doi.org/10.2307/3588452

Lantolf, J. P., \& Genung, P. A. (2002). "l'd rather switch than fight": An activity-theoretic study of power, success, and failure in a foreign language. In C. Kramsch (Ed.), Language acquisition and language socialization: Ecological perspectives. London, England: Continuum.

Lantolf, J. P., \& Pavlenko, A. (2001). Second language activity theory: Understanding second language learners as people. In M. P. Breen (Ed.), Learner contributions to language learning: New directions in research (pp. 141-158). New York, NY: Longman.

Lantolf, J. P., \& Thorne, S. L. (2006). Sociocultural theory and the genesis of second language development. Oxford, England: Oxford University Press.

Lantolf, L. P., \& Thorne, S. L. (2007). Sociocultural theory and second language learning. In B. V. P. J. Williams (Ed.), Theories in second language acquisition: An introduction (pp. 693-701). New York: Lawrence Erlbaum.

Leontiev, A. N. (1979). Activity, consciousness and personality. Englewood Cliffs, NJ: Prentice Hall.

Lyle, J. (2003). Stimulated recall: A report on its use in naturalistic research. British Education Research Journal, 29(6), 861-878. http://dx.doi.org/10.1080/0141192032000137349

Morita, N. (2004). Negotiating participation and identity in second language academic community. TESOL Quarterly, 38(4), 573-603. http://dx.doi.org/10.2307/3588281

Norton, B. (2001). Non-participation, imagined communities and language classroom. In M. P. Breen (Ed.), Learner contributions to language learning: New directions in research (pp. 159-182). New York, NY: Longman. 
Norton, B., \& Toohey, K. (2001). Changing perspectives on good language learners. TESOL Quarterly, 35(2), 307-322. http://dx.doi.org/10.2307/3587650

Norton, B., \& Toohey, K. (2011). Identity, language learning, and social change. Language Teaching, 44(4), 412-446. http://dx.doi.org/10.1017/S0261444811000309

Nunan, D. (2004). Task-based language teaching. Cambridge, England: Cambridge University Press. http://dx.doi.org/10.1017/CBO9780511667336

Parks, S. (2000). Same task, different activities: Issues of investment, identity and use of strategy. TESL Canada Journal, 17(2), 64-88. http://dx.doi.org/10.18806/tesl.v17i2.890

Sirisatit, R. (2010). An activity theory perspective on task-based instruction in a university business EFL class in Thailand: A sociocultural case study. Unpublished doctoral thesis, University of Pittsburgh, Pittsburgh, Pennsylvania.

Skinnari, K. (2014). Silence and resistance as experiences and presentations of pupil agency in Finnish elementary school English lessons. Journal of Applied Language Studies, 8(1), 47-64.

Tran, T. T. T., \& Richard, B. B. J. (2007). Demotivation: Understanding resistance to English language learning - The case of Vietnamese students. The Journal of Asia TEFL, 4(1), 79105.

Vygotsky, L. S. (1978). Mind in society: The development of higher psychological processes. Cambridge, MA: Harvard University Press.

Yashima, T. (2012). Agency in second language acquisition. The encyclopedia of applied linguistics. http://dx.doi.org/10.1002/9781405198431.wbeal0016 